\title{
Chronicling teachers' experiences on integrating information and communication technology across the curriculum
}

\begin{tabular}{|c|c|}
\hline $\begin{array}{l}\text { Author: } \\
\text { Babalwa P. Ka }\end{array}$ & u-Quvane ${ }^{1,2}$ (๑) \\
\hline $\begin{array}{l}\text { Affiliations: } \\
\text { }{ }^{\text {Department }} \\
\text { Further and C } \\
\text { Education, Fa } \\
\text { Education, Un } \\
\text { Hare, Alice, Sc }\end{array}$ & $\begin{array}{l}\text { chool of } \\
\text { ontinuing } \\
\text { ulty of } \\
\text { iversity of Fort } \\
\text { uth Africa }\end{array}$ \\
\hline $\begin{array}{l}{ }^{2} \text { Department } \\
\text { Science and } \mathrm{H} \\
\text { Faculty of Edu } \\
\text { University of } \\
\text { Durban, South }\end{array}$ & $\begin{array}{l}\text { ff Social } \\
\text { umanities, } \\
\text { cation, } \\
\text { iwaZulu-Natal, } \\
\text { Africa }\end{array}$ \\
\hline $\begin{array}{l}\text { Research Proj } \\
\text { Project Numb }\end{array}$ & $\begin{array}{l}\text { ect Registration: } \\
\text { er: } 215082419\end{array}$ \\
\hline $\begin{array}{l}\text { Correspondin } \\
\text { Babalwa Kafu } \\
\text { bkafu-quvane }\end{array}$ & $\begin{array}{l}\text { g author: } \\
\text { Quvane, } \\
\text { @ufh.ac.za }\end{array}$ \\
\hline $\begin{array}{l}\text { Dates: } \\
\text { Received: } 11 \\
\text { Accepted: } 05 \\
\text { Published: } 23\end{array}$ & $\begin{array}{l}\text { Jov. } 2020 \\
\text { Jct. } 2020 \\
\text { Mar. } 2021\end{array}$ \\
\hline $\begin{array}{l}\text { How to cite th } \\
\text { Kafu-Quvane } \\
\text { teachers' expe } \\
\text { integrating inf } \\
\text { communicatic } \\
\text { across the cur } \\
\text { J Transdiscipl } \\
2021 ; 17(1) \text {, a } \\
\text { org } / 10.4102 / t\end{array}$ & $\begin{array}{l}\text { is article: } \\
\text { 3P. Chronicling } \\
\text { riences on } \\
\text { ormation and } \\
\text { n technology } \\
\text { riculum. } \\
\text { Res S Afr. } \\
\text { 83. https://doi. } \\
\text { d.v17i1.783 }\end{array}$ \\
\hline $\begin{array}{l}\text { Copyright: } \\
\text { (C) 2021. The } \\
\text { Licensee: AOS } \\
\text { is licensed un } \\
\text { Creative Comr } \\
\text { Attribution Lio }\end{array}$ & $\begin{array}{l}\text { luthors. } \\
\text { IS. This work } \\
\text { ler the } \\
\text { nons } \\
\text { ense. }\end{array}$ \\
\hline Read online: & \\
\hline 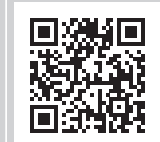 & $\begin{array}{l}\text { Scan this QR } \\
\text { code with your } \\
\text { smart phone or } \\
\text { mobile device } \\
\text { to read online. }\end{array}$ \\
\hline
\end{tabular}

\begin{abstract}
The national curriculum in South Africa demands that children in secondary schools become computer literate and that schools incorporate information and communication technology (ICT) into the curriculum. This is not feasible, as computer equipment is not evenly distributed in schools across the country. Drawing on the experiences of teachers from four high schools captured in focus group discussions, the researcher explores teachers' experiences in managing teaching in an era of incorporating ICT in teaching. The findings suggest that on all the management functions (planning, organising and leading) teachers had more negative than positive experiences with ICT integration and largely negative experiences with training and organising.
\end{abstract}

Keywords: integration; information and communication technology; chronicling; experiences; curriculum.

\section{Introduction}

The national curriculum in South Africa demands that children in secondary school become computer literate and schools integrate information and communication technology (ICT) across the curriculum. ${ }^{1}$ The DoE's ICT policies underestimate the importance of preparing teachers for integrating such technologies into their classroom practice. The policies epitomise a one-size-fits-all approach and are not formulated in such a way as to cater for diverse school environments. ${ }^{2}$

The practicability of integrating ICT is not practicable and it poses challenges in some South African schools, because the distribution of gadgets by the DoE is uneven. The 'onelaptop-per-teacher initiative' has not materialised, as teachers are expected to secure personal finance to buy laptops before claiming from the DoE - worryingly, many teachers are not considered creditworthy by the banks. ${ }^{3}$

Research shows that governments around the world invest significant sums of money in ICT to improve teaching in schools. In the United Kingdom, for example, between 2008 and 2009 , related expenditure amounted to $£ 2.5$ billion, the United States spent $\$ 600$ million and New Zealand invested NZ410m in schools' ICT infrastructure. ${ }^{4}$ Despite these massive investments in ICT equipment and the significant benefits of integrating ICT into the curriculum, there is little knowledge about what teachers are experiencing on the ground. There is thus a need to understand local teachers' experiences in managing teaching using ICT, as that will inform government's efforts.

Having been a teacher at a secondary school, the researcher witnessed hands-on experience facing many of the challenges confronting teachers in integrating ICT into their classroom practice. Thus, for a complete picture, it was crucial to interrogate teachers' experiences, revisit the policy statements and gather teachers' own perceptions on ICT integration. Their knowledge and feedback will assist in encouraging others to develop innovative ways of teaching and will help to transform policy statements into reality.

\section{Teachers' experiences of information and communication technology integration into the curriculum}

According to Ghavifekr et al. ${ }^{5}$ integrating ICT into teaching requires input from teachers. Once they understand how ICTs simplify their work, they can restructure the learning environments 
and adopt innovative teaching methods. Teachers need time to discover that using computers does not mean extra work, but rather simplifies their work. ${ }^{6}$

Ghavifekr et al. ${ }^{5}$ posit that effective ICT integration in classroom practice includes teachers' involvement in policymaking and practices, which consider the processes by which teachers learn technical skills, as well as the social, cultural and historical contexts of learning. The deputy principal working with Heads of Department is responsible for facilitating the integration of ICT into teaching and learning, by establishing policy, which aligns with that of government, and nurturing positive relationships amongst teachers. The more teachers display teamwork fundamentals, the more opportunities there are for learners to learn skills related to collaboration and compromise. ${ }^{7}$ Stakeholders involved in education must be motivated, and their attitudes and beliefs must be transformed so that they all work as one team with one vision.

Resistance to change is a challenge facing those attempting to integrate ICT into the curriculum. Change can generate resistance and scepticism in teachers, making it difficult (or impossible) to implement organisational improvements. Similarly, Ghavifekr and Rosdy ${ }^{9}$ observed that employees tend to resist change within their organisation.

\section{How teachers integrate information and communication technology across the curriculum}

A study by Du Plessis ${ }^{10}$ on South African schools' readiness for computer implementation reports that three types of ICT integration are prevalent in our schools: The first focuses on implementation without integration, resulting in computer literacy that merely involves using technology without linking it to what is happening in the classroom. This occurs in schools where, instead of integrating ICT into the classroom content, learners are taught computer skills. The second results in learning from the computer, where the computer becomes the tutor or transmitter of knowledge. The last refers to learning 'with' or 'through' the use of computers (i.e. generative use), where computers become cognitive, mediational or transformational tools. In most South African schools, the generative mode of integration is not the norm..$^{10}$ Integrating ICT into the curriculum is not only about information processing, but it also involves the transmission of information for educational development. In addition, integrating ICT across the curriculum makes the traditional teacher a facilitator in learning with and through ICT. Ghavifekr et al. ${ }^{5}$ are of the opinion that such integration differs from country to country, from one school to another and from resourced to underresourced schools. Information and communication technology integration differs depending on context, for example, between developed and developing countries and between rural and urban areas. Information and communication technology must therefore be thoughtfully selected and integrated into educational planning and management to be effective.

\section{Conceptual framework}

In the researcher's view, in order to understand teachers' experiences of ICT integration across the curriculum, it is crucial to consider the notions of 'management task' and the context in which they operate on the other hand, the management area.

An understanding of these notions would help in the analysis of management actions of teachers by distinguishing between actions on the one hand and the areas in which tasks are carried out on the other hand. Management, as part of the process of achieving the set objectives, emphasises using the necessary people and resources as effectively as possible. In that sense, managing is a social activity involving the relationships between people. ${ }^{11}$ Besides, management involves making the right decisions, fulfilling or achieving set goals. In a school, there must be a continuous understanding of and balance between conflicting interests to facilitate the achievement of goals through the coordination of different tasks.

The first step in the management process entails the management task of planning, as it gives purpose and direction to the school. Different people at different levels do planning, because no school exists in isolation. ${ }^{11}$ Planning is thus an interrelated, interactive and interdependent process. According to Bush, ${ }^{2}$ organising in the context of a school entails allocating work amongst the staff for teaching and learning to take place efficiently.

Research shows that organising involves creating a structure for the organisation that will work effectively to achieve and realise organisational outcomes, coordinate tasks and establish formal relationships between the people performing the tasks.,12 Management involves leading that entails influencing people in such a way that they willingly work and strive to achieve the goals of the group. Leaders activate others in the quest to achieve set goals. Leading gives direction to a common activity by ensuring that people execute specific tasks in working towards reaching predetermined goals. Supportive actions of guidance are learned - certain skills are needed, such as the ability to build relationships, motivate and communicate. Motivating teachers to carry out specific tasks requires purposeful communication.

\section{Methodology}

This study is based on the interpretivist paradigm, which assumes that human life can only be studied from within. ${ }^{13}$ What drives research of this nature is the need to understand and describe meaningful social action. In chronicling teachers' experiences in managing teaching in respect of ICT curriculum integration, the research techniques used will give a great opportunity in understanding the perceptions they have of their own activities.

The researcher adopted a qualitative exploratory case study. $Y_{i n}{ }^{14}$ maintained that a case study involves an investigation 
into a present-day phenomenon occurring within a bounded, real-world situation, adding that contextual factors largely determine the nature of the situation within which the phenomenon manifests. The researcher chose a case study because it can provide in-depth, thick and rich descriptions of a particular case. It is also flexible in terms of what is studied, versatile and manageable in research situations. ${ }^{13}$ The researcher selected a familiar topic and a study sample she had access to.

The study employs purposeful sampling for both the schools and the participants. This involved choosing people who, in the researcher's view, could provide sufficient information that would be relevant to the study. In this instance, the participating schools made use of ICT equipment, the researcher consulted teachers for first-hand information based on their expert knowledge and professional insights. These participants were selected appropriately and purposively not only for their knowledge but also for their potential impact on the study.

The district schools and teachers who formed part of the study met the requirements, as the four schools selected were piloting ICT integration and, to this end, had been supplied with equipment by the DoE. The participating teachers taught different subjects at their respective schools. The selected secondary schools had well-resourced computer laboratories, laptops on trollies, tablets and Wi-Fi internet connectivity.

The researcher used focus group interviews as a datageneration instrument, with a view to interrogating teachers' experiences through shared interaction. In addition, focus group interviews can be useful in a school setting where teachers naturally form groups based on different subject departments, unions, religious beliefs, etc. This type of interview grants the participants an opportunity to clarify and modify their ideas during discussions with their fellow participants. Members are free to disagree, thereby ensuring that the experiences and views of a group are articulated satisfactorily and comprehensively.

Using focus group interviews enabled the researcher to explore various opinions and generate insights into how ICT is integrated into the curriculum in practice. The participants shared certain common characteristics, for example, they were all post level one teachers, and thus interaction happened at an optimum level without any individual being dominant. The two main research questions were put to the participants (in turn), who identified key areas and probed the topic. The researcher improvised the probing, to encourage open, interactive discussion, creating an atmosphere that put all the participants at ease, before asking questions in a conversational tone. The one-and-a-half-hour focus group revealed rich data on teachers' experiences of integrating ICT across the curriculum.

The researcher used thematic analysis to analyse data, because it involves a careful, focused re-reading and review of the data. The researcher identified recurring themes, considered the context of their use and examined the strength of the feelings of the participants, before categorising the themes and sub-themes emerging from the analysed responses. To ensure that the voice of the participants would not be lost, the researcher used verbatim quotes in the data presentation, pseudonyms to identify the schools and abbreviated codes to identify the focus groups.

\section{Ethical consideration}

The ethical clearance to conduct this study was obtained from the University of KwaZulu-Natal (ethical clearance number: HSS/0024/017M).

\section{Findings of the study}

In this section, the findings of the study are presented as verbatim narrations.

\section{Teachers' experiences of integrating information and communication technology across the curriculum}

The researcher raised the challenges teachers faced with ICT integration and they were discussed in detail. Their experiences were shaped by the strategies they employed when planning. In this, the School Management Team (SMT) and departmental officials guided them.

\section{Experiences regarding planning}

The question the researcher asked the groups was how they planned to use ICT in teaching and learning, more broadly as regards planning. A variety of levels of planning emerged: some participants referred to planning at the broader level of the school, others discussed it at an individual level. A participant from Sango High School (SHS) noted as given in the following section.

\section{The school never planned for the incorporation of information and communication technology in teaching}

A participant from Tanga High School (THS) added:

'[O]ur school did not plan for the incorporation of computers in teaching. We are not forced to use the equipment in teaching and learning. We do not have an ICT policy and an ICT committee as well. Some teachers do not have access to the equipment. Those who use the equipment work in isolation; we have technical and financial problems at times. Most of us do not use the equipment because it is inaccessible. We are pulled away from integrating ICT ...' (Teacher A, THS)

\section{A participant from Owam High School (OHS) stated:}

'[There is] no planning. We have an ICT committee, on paper, [but] it is dysfunctional. The DoE delivered the equipment; no planning was done at the school for its use. There is no cooperation on using ICT equipment. Nobody checks if everything occurs in confirmation with the plans. Even when one deviates from his or her plans, she or he is not accountable. The computer laboratory is used as a classroom because of infrastructure problems. Electricity and internet provision is 
not reliable. The tablets we had were not connecting to Google; it was only Thutong [South African Education Portal] and digital classrooms, which are not of much importance. Our Wi-Fi is always offline, because the school cannot afford to pay for it.' (Teacher A, OHS)

On the same matter, one participant from Yethu High School (YHS) expressed the following view:

'There is no school plan on using the equipment, we do planning as individual teachers for our classroom teaching, and for example, in Life Sciences we use the equipment to project experiments. We do not work as a team this, for example, the SMT does not assist with time-tabling the use of the equipment, so we end up fighting amongst ourselves, that is why some of us end up with some kind of resistance.' (Teacher A, YHS)

The researcher sought further information on why there was a lack of planning for ICT integration at the school level. Some participants stated that the SMT members were unable to use the ICT equipment, so it would be futile planning for them to use it. As one of the SOE participants noted:

'The SMT members are all computer illiterate.' (Teacher B, SOE)

Other participants mentioned that most teachers are computer illiterate; thus, there was no point in planning to use technology in teaching. A participant from $\mathrm{OHS}$ stated:

'Some of us are computer illiterate, we are afraid of using the equipment in front of learners, in case it fails.' (Teacher B, OHS)

One participant from THS described planning at an individual level, reporting that he incorporated ICT in his lesson planning:

‘Lucky me, I incorporate ICT in my lesson planning. In my lesson plan, I indicate the times that I set aside to show YouTube videos to my learners.' (Teacher B, THS)

When asked why individual departments (e.g. Physical Science) did not plan as a collaborative unit, one participant responded that integrating ICT was forced on them:

'It was imposed on us, the DOE supply the computers, so we were never ready for the integration and we are not comfortable with using ICT equipment.' (Teacher C, THS)

The groups mentioned different planning issues, but overall it appears that no planning (not even scheduling the use of ICT equipment) was being carried out. At all four schools, there was no planning for ICT integration and development, which would involve providing administrative support for computer facilities, ordering supplies, maintaining software and hardware or collaborating with teachers to prepare hardware and software budgets, reports and proposals. ${ }^{1}$ Those who integrated ICT in their pedagogy did so whilst doing their own individual planning.

As the study showed, a gap thus existed between what was happening in the researched schools and what the literature states about the importance of incorporating ICT in planning. The purpose of planning for teachers and for the school is to make sure that the decisions taken on the use of resources are based on the school policy.

The planning aspect of teaching is crucial, in that it alone may determine the success or failure of the educator as a manager. Different stakeholders, at different levels and times, do planning - there is always an interaction between the school and the parents, officials from the provincial office and the national office. Bush and Glover ${ }^{11}$ claimed that, for plans to be successful, the concepts of vision, mission, aims and outcomes must be directed at achieving specific results in the future. The vision of the DOE helps SMTs develop missions for their schools, which drive all stakeholders to formulate very specific related aims. These aims can only be achieved if they are specified and detailed. Once all stakeholders accept an ICT vision, it should become a shared vision, which can be translated into reality.

\section{Participants' experiences regarding organising}

The school, as an organisation, has many members. It is possible for an individual to lose track of the school's aims if she or he works alone.

Under this sub-theme, the researcher investigated the organisational structure of the participating schools to determine how teachers organised their teaching and how ICT resources were distributed. The participants gave a common perspective, reporting a top-down management approach in their schools. This is how one participant from YHS expressed as below:

'In our school, we get all the orders from the principal. This does not assist us. We have staff members with good computer skills, but these are not put to good use, since they are not in the SMT.' (Teacher B, YHS)

\section{A participant from THS added as given below:}

'Management in our school is from the principal to the staff and from the staff to the learners. Nobody is responsible for ICT, we work as individual teachers and there are issues with using the ICT equipment, but we ignore them.' (Teacher C, THS)

As regards the second question about how teachers organised their teaching, one participant from OHS explained that it is difficult to use ICT effectively in teaching because of a lack of cooperation amongst colleagues as mentioned below:

'It is the survival of the fittest. It is first come, first served on using the resources. Sometimes things do not go according to your plans.' (Teacher $\mathrm{C}, \mathrm{OHS}$ )

On the same matter, a participant from YHS explained that management did not provide sufficient administrative support as mentioned below:

'The equipment (data projector, smart board) is mounted in the Physical Science classroom, so it is always available to the people teaching there. We have limited resources, only two laptops. There is always a power failure. You plan to use the laboratory and the electricity goes off. Sometimes we need support on using the equipment, for example, when the 
computer does not communicate with the smart board, having planned to use it in class, it does not work, then you look like a fool in front of the learners. Nobody is in control of ICT resources.' (Teacher C, YHS)

Participants from SOE stated that the lack of collaboration between teachers and SMTs in respect of the maintenance and preparation of hardware and software made it difficult for them to organise their teaching.

As one participant noted as below:

'The tablets that were stolen were not replaced, same with the broken equipment - it is not repaired. The same computer laboratory is used as a classroom. There is no scheduling or timetable on the use of the equipment. With the little time we get after hours, we use the little equipment the school has.' (Teacher C, SOE)

When asked how cooperation and effectiveness could be enhanced in the integration of ICT in teaching, some teachers expressed the view that continuous support from the SMTs and departmental officials would be very helpful. This is how a participant from YHS responded as below:

'The department officials must provide support once the ICT equipment is delivered to our schools.' (Teacher D, YHS)

\section{A participant from OHS noted as below:}

'The school management must provide support, by making sure that all teachers are computer literate and are able to integrate ICT in teaching and learning. There must be an ICT policy to guide us.' (Teacher D, YHS)

Another view was that effective ICT integration in practice largely depends on individual teachers as mentioned below:

'As teachers, it is important that we upgrade ourselves in ICT and assist each other with integrating ICT in teaching and learning ... It is our responsibility to keep up and blend our traditional teaching methods with ICT.' (Teacher E, OHS)

Other participants argued that the effectiveness of ICT integration depends on SMTs. As one participant explained as below:

'The SMT must be workshopped on using the ICT. The HODs [heads of department] are not well versed [in] ICT, so it is hard for them to monitor teachers on integration.' (Teacher F, OHS)

It appeared as if, in all the participating schools, responsibility, authority and accountability were not in balance: authority was vested in one figure, the principal, from whom staff received instructions and to whom they were accountable. The teachers seemed unable to organise their teaching using ICT, as there was no ICT coordinator. They received no guidance on the use of technology. Those who integrated ICT did so individually, thus only those who were skilled at related technologies, succeeded. The school's organogram determines that, in order to work together effectively to achieve the outcomes of the organisation, tasks must be coordinated and formal relationships created between the people performing those tasks. ${ }^{12}$
As the participants stated, the SMT must facilitate the integration, by establishing a policy, which aligns with that of government. This body must also ensure that a positive working relationship is established amongst teachers. To be optimally effective, teamwork must involve teachers, learners and parents. A lack of cooperation, which was evident in the researched schools, negates the advice of Koontz and $\mathrm{O}^{\prime}$ Donnell, ${ }^{7}$ who aver that if teachers work as a team, their learners will learn from their example.

To ensure an effective culture of teaching and learning, teachers should carry out their tasks effectively. The way in which tasks are handled and resources are distributed amongst teachers and departments should be based on organisational structures, divisions of work and established relationships. ${ }^{2}$ The clear division of work is important for maintaining order in schools, whilst organisational structures are helpful for analysing, grouping, dividing and controlling the planned outcomes of a school. Establishing harmonious interpersonal relationships is significant if the aims and outcomes of the school are to be achieved.

\section{Experiences regarding leading}

Leading as a management task involves the execution of plans by putting all resources to work. That means making sure that teachers use the resources available to achieve the short- and long-term goals set during the planning stage. Leading influences people so that they willingly work and strive to accomplish the goals. People have to be mobilised to achieve their desired goals. Under this theme, the question was whether the teachers played a leading role in integrating ICT in their classrooms. One participant from THS described how he went the extra mile to achieve the below:

'When I teach literature in English, I organise videos for different books that are studied in a particular year. The students take turns watching them on my laptop, but the negative side is that I carry the costs alone for the data that I use when streaming videos. As a result, most teachers are not motivated to integrate ICT into the curriculum.' (Teacher D, THS)

Another participant from YHS stated that the SMT plays a leading role in motivating teachers to strive to integrate ICT in their classrooms:

'There is an SMT member who is always willing to assist, he leads us but there are very few of us [teachers] who comply.' (Teacher E, YHS)

The OHS participants were of the view that the leading role they played was not beneficial because of a lack of support from the SMT. As one participants explained as below:

'We push ourselves, at our own pace. If you do not want to integrate ICT, you simply teach using traditional methods. There is no communication.' (Teacher G, OHS)

The way teachers led the integration of ICT in their classrooms was not uniform. In some schools, teachers had the support 
of the SMT; few teachers led the integration process, claiming they did not receive guidance or motivation; there was little communication; and establishing relationships was not a priority. It is important for school management to consider the feelings of teachers, and to direct them towards effective teaching. Therefore, motivating teachers will guide them to become effective leaders. Motivating teachers to carry out specific tasks, such as using ICT in their everyday teaching, requires purposeful communication. As building relationships in the school is vital, the principal should establish strong relationships with and between teachers, learners, administrative staff and other stakeholders.

Some of the challenges teachers faced could be related to a lack of planning on the part of the school. Clearly, no planning (e.g. scheduling equipment usage) was carried out. At one school, the participants reported a lack of cooperation between the district and the school's SMT. Some reported that vandals from the community destroyed school property. At another school, the participants reported having limited access to equipment, so they ended up using their own personal gadgets. They also complained about unreliable electricity supply and Internet access, and the fact that stolen equipment was not replaced.

The YHS participants stated that when something new was introduced into the system, there was resistance from certain staff members, because any form of change made them uncomfortable. As Abrheim ${ }^{8}$ noted, change can generate resistance and scepticism amongst teachers, making it difficult or impossible to implement organisational improvements. In some instances, resistance to change stems from a lack of information. In addition, without a plan, there is nothing to organise, guide or control in the first place.

\section{Conclusion and recommendations}

Informed by the research journey, the author concluded that teachers had more negative experiences with ICT integration than positive ones. These negatives included insufficient ICT resources, timetable clashes in using equipment, a lack of ICT skills, inadequate ICT integration training, negative attitudes and a lack of confidence in using the gadgets. The few positive experiences reported included improved access to the required information and greater collaboration amongst teachers. Currently, efforts to incorporate ICTs in the curriculum do not appear to be bearing fruit.

The following recommendations can be made based on this study:

- Strong, committed leadership is needed to support the goals of ICT integration, through the establishment of ICT committees and the election of ICT lead teachers. The school management is encouraged to work with teachers in formulating an ICT policy so that its implementation is binding on all staff.

- Based on the finding that ICT integration was poor because of limited training, each school is encouraged to provide teachers with computer training and make sure that they are able to integrate related technologies into their pedagogical activities.

- The school's readiness to incorporate ICTs is of utmost importance. Every school is different and should be given the autonomy to select the most necessary ICT resources, given the needs of its teachers and learners. The SMT should adopt strategies to increase teachers' familiarity with ICT. Examples include using e-mail communication with staff or the intranet to download lesson plan templates for submission. As teachers become adept at using technology, integrating it into their teaching and learning will be a smooth process.

\section{Acknowledgements Competing interests}

The author declares that she has no financial or personal relationships that may have inappropriately influenced her in writing this research article.

\section{Author's contribution}

B.P.K.-Q. is the sole author of this research article.

\section{Funding information}

This research received no specific grant from any funding agency in the public, commercial or not for profit sectors.

\section{Data availability}

The authors confirm that the data supporting the findings of this study are available within the article.

\section{Disclaimer}

The views and opinions expressed in this article are those of the author and do not necessarily reflect the official policy or position of any affiliated agency of the author.

\section{References}

1. Department of Education (DOE). Transforming learning and teaching through Information and Communication Technology (ICTs). White Paper 7 on e-education. Pretoria: Government Press; 2004.

2. Bush T. Organisation theory in education: How does it inform school leadership? J Organisat Theor Educ. 2015;1(1):35-47.

3. Mail \& Guardian. Training part of the teacher laptop initiative [serial online] [cited 2010 Aug 16]. Available from: http://mg.co.za/article/2010-08-16-trainingpart-of-the-teacher-laptop-initiative

4. Buabeng-Andoh $\mathrm{C}$. Factors influencing teachers' adoption and integration of ICT into teaching: A review of literature. Int J Educ Dev. 2012;8(1):136-155.

5. Ghavifekr S, Razak AZA, Ghani MFA, Ran NY, Meixi Y, Tengyue Z. ICT integration in education: Incorporation for teaching \& learning improvement. Malays Online J Educ Technol. 2014;2(2):22-45.

6. Hennessy S. Teacher factors influencing classroom use of ICT in sub-Saharan Africa. Itupale Online J Afr Stud. 2010;2(1):39-54.

7. Koontz H, O'Donnell C. Principles of management: An analysis of managerial functions. New York, NY: McGraw Hill; 2011.

8. Abrheim TH. Managing transformation and change for the business leader. Bus Manag Rev. 2013;3(2):14-22.

9. Ghavifekr S, Rosdy WA. Teaching and learning with technology: Effectiveness of ICT integration in schools. Int J Res Educ Sci. 2015;1(2):175-191. 
10. Du Plessis A. Teacher's perceptions about their own and their schools readiness for computer implementation: A South African case study. Turkish Online J Educ Technol. 2012;11(3):1-15.

11. Bush T, Glover D. School leadership and management in South Africa: Findings from a systematic literature review. Int J Educ Manag. 2016;30(2):211-231. https://doi.org/10.1108/IJEM-07-2014-0101
12. Marishane R, Botha RJ, Du Plessis P. School leadership in a changing context: A case for school-based management. Pretoria: Van Schaik; 2011.

13. Creswell JW, Creswell JD. Research design: Qualitative, quantitative, and mixed methods approaches. Thousand Oaks, CA: Sage; 2017.

14. Yin KR. Case study research design and methods. Thousand Oaks, CA: Sage; 2014. 